\title{
Effect of protection against pathogens on yield of two breeding types of winter oilseed rape cultivars under high level of nitrogen fertilization
}

\author{
Wpływ ochrony przed patogenami na plonowanie \\ dwóch typów hodowlanych odmian rzepaku ozimego \\ w warunkach wysokiego poziomu nawożenia azotem
}

\author{
Marek Wójtowicz $^{1}{ }^{*}$, Ewa Jajor $^{2}$, Andrzej Wójtowicz $^{2}$, Marek Korbas $^{2}$, Franciszek Wielebski ${ }^{1}$
}

\begin{abstract}
Summary
The carried out studies confirmed the efficacy of chemical protection in reduction of infection caused by the following pathogens; Leptosphaeria spp. - phoma stem canker, Sclerotinia sclerotiorum - stem rot, Botryotinia fuckeliana - grey mould, Alternaria spp. - dark leaf and pod spot. In all plant protection programs the treatments were applied at the growth stage BBCH 65 which, was recommended for a control of pathogens occurring at highest intensity during the studies (S. sclerotiorum and Alternaria spp.) and it resulted in similar efficiency of protection. Plant protection also significantly affected the yield. The highest seed yield was collected from the objects protected three times during a vegetation season. The seed yield was also dependent on nitrogen fertilization level. Significant higher seed yield was achieved on objects fertilized with $220 \mathrm{~kg} \mathrm{~N} / \mathrm{ha}$. Seed yield was also influenced by cultivar and sowing density. Visby cultivar produced a significantly higher yield when sown at smaller density.
\end{abstract}

Key words: program of plant protection; spring nitrogen fertilization; winter oilseed rape cultivar

\section{Streszczenie}

Przeprowadzone badania potwierdziły skuteczność ochrony chemicznej w ograniczaniu nasilenia porażenia przez sprawców chorób (Leptosphaeria spp. - sucha zgnilizna kapustnych, Sclerotinia sclerotiorum - zgnilizna twardzikowa, Botryotinia fuckeliana - szara pleśń, Alternaria spp. - czerń krzyżowych). Podobna efektywność sposobów ochrony była konsekwencją uwzględnienia we wszystkich programach zabiegu $\mathrm{w}$ fazie $\mathrm{BBCH} 65$ zalecanego do zwalczania patogenów występujących w największym nasileniu w okresie prowadzenia badań czyli S. sclerotiorum i Alternaria spp. Ochrona przed patogenami również istotnie oddziaływała na plon nasion. Najwyższe plony zebrano z obiektów, na których rzepak był chroniony trzykrotnie w sezonie wegetacyjnym. Wysokość plonu zależała także od poziomu nawożenia azotem. Istotnie wyższe plony uzyskano na obiektach nawożonych azotem w dawce $220 \mathrm{~kg} \mathrm{~N} / \mathrm{ha}$. Także odmiana i ilość wysiewu decydowały o poziomie plonowania. Istotnie wyżej plonowała rzadziej wysiana odmiana Visby.

Słowa kluczowe: program ochrony roślin; wiosenne nawożenie azotowe; odmiana rzepaku ozimego

\footnotetext{
Instytut Hodowli i Aklimatyzacji Roślin - Państwowy Instytut Badawczy

Oddział w Poznaniu

Strzeszyńska 36, 60-479 Poznań

${ }^{2}$ Instytut Ochrony Roślin - Państwowy Instytut Badawczy

Władysława Węgorka 20, 60-318 Poznań

*corresponding author: marekw@nico.ihar.poznan.pl
} 


\section{Wstęp / Introduction}

Rzepak ozimy przez cały okres wegetacji narażony jest na porażenie przez sprawców chorób. Nasilenie objawów chorobowych zależne jest zarówno od kontrolowanej genetycznie odporności odmian (Starzycka i wsp. 2009), jak i oddziaływania czynników środowiskowych. Zwłaszcza warunki pogody znacząco wpływają na porażenie roślin, któremu sprzyja ciepła jesień oraz deszczowa wiosna (Mączyńska i wsp. 2001; Kurowski i Budzyński 2003). Kolejnym czynnikiem oddziałującym na nasilenie porażenia jest nawożenie mineralne (Marschner 1995). Sadowski i wsp. (2002) wykazali wzrost porażenia rzepaku nawożonego wyższymi dawkami azotu przez Erysiphe cruciferarum i Peronospora parasitica. Z kolei Jankowski i Budzyński (1997) oraz Kurowski i Budzyński (2003) w warunkach wysokiego poziomu nawożenia azotem obserwowali większe porażenie rzepaku przez Botrytis cinerea. Również badania przeprowadzone przez Podleśną i wsp. (2005) wskazują $z$ reguły na wzrost nasilenia infekcji chorobowych przy wyższym poziomie nawożenia tym składnikiem. Obok prac opisujących istotny wpływ nawożenia azotem na stopień porażenia roślin są również doniesienia, w których autorzy nie wykazują tego związku. Wyniki prezentowane przez Sadowskiego i wsp. (1988), Lemańczyka i wsp. (1997), Söchting i Verreet (2004) oraz Wójtowicza (2013) wskazują na brak oddziaływania poziomu nawożenia azotem na porażenie rzepaku przez Leptosphaeria spp. Podobnie Lemańczyk i wsp. (1997) oraz Sadowski i wsp. (1998) podkreślają brak związku pomiędzy poziomem nawożenia azotem a intensywnością występowania S. sclerotiorum. Natomiast prace Jankowskiego i Budzyńskiego (1997), Söchting i Verreet (2004) oraz Wójtowicza (2013) wskazują na ograniczenie porażenia przez $S$. sclerotiorum rzepaku intensywnie nawożonego azotem. Efektywnym sposobem ochrony roślin przed patogenami są zabiegi chemiczne z zastosowaniem fungicydów (Gladders i wsp. 1998; Wohlleben i Verreet 2002). Brak jednoznacznych wyników wskazuje na potrzebę kontynuacji prac ukierunkowanych na wyjaśnienie związku nawożenia azotowego z rozwojem objawów chorobowych. Istnieje również potrzeba prowadzenia systematycznych badań nad efektywnością ochrony chemicznej. Skuteczność zabiegów chemicznych zależna jest od terminu ich przeprowadzenia oraz intensywności ochrony.

Celem prezentowanej pracy było określenie znaczenia intensywności ochrony nie tylko w ograniczeniu nasilenia porażenia, ale przede wszystkim w zapobieganiu stratom plonu. Niejednakowa odporność odmian na porażenie przez patogeny uzasadnia podejmowanie badań, których celem jest określenie reakcji odmian na intensywność zabiegów ochronnych. Interesujące jest czy efektem intensyfikacji ochrony będzie istotne zróżnicowanie plonów ocenianych odmian.

\section{Materiały i metody / Materials and methods}

Trójczynnikowe doświadczenie realizowano w latach 2009, 2010, 2011, w miejscowości Łagiewniki (N51²46'
E17 $\left.{ }^{\circ} 4^{\prime}\right)$ w układzie podbloków (split-split plot) w czterech powtórzeniach. Czynnikiem pierwszego rzędu były 3 programy ochronne stosowane na tle kontroli bez zabiegów fungicydowych. Najintensywniej chroniono rzepak stosując fungicydy jesienią w fazie 6 liści - BBCH 16 oraz wiosną $\mathrm{w}$ fazie formowania łodyg - BBCH 33 i opadania pierwszych płatków kwiatowych - BBCH 65. Mniej intensywne warianty ochrony polegały na stosowaniu fungicydów jesienią $\mathrm{w}$ fazie - $\mathrm{BBCH} 16$ oraz wiosną $\mathrm{w}$ fazie - BBCH 65 lub wyłącznie wiosną w fazach - BBCH 33 i BBCH 65. Jesienią zastosowano fungicyd Horizon ${ }^{\mathrm{TM}}$ 250 EW (tebukonazol - $250 \mathrm{~g} / \mathrm{l}$ ) w dawce 0,75 l/ha, wczesną wiosną fungicyd Caramba ${ }^{\mathrm{TM}} 60 \mathrm{SL}$ (metkonazol $60 \mathrm{~g} / \mathrm{l}) \mathrm{w}$ dawce 1,25 l/ha, a w czasie kwitnienia fungicyd Pictor $^{\text {TM }} 400$ SC (dimoksystrobina - 200 g/l, boskalid $200 \mathrm{~g} / \mathrm{l}) \mathrm{w}$ dawce 0,5 1/ha. W ramach czynnika drugiego rzędu zastosowano dwa poziomy nawożenia azotowego (160 i $220 \mathrm{~kg} \mathrm{~N} / \mathrm{ha}$ ). Czynnikiem trzeciego rzędu był typ hodowlany rzepaku reprezentowany przez dwie odmiany wysiane w różnej ilości wysiewu. Odmianę populacyjną Casoar wysiano w ilości 80 nasion na $\mathrm{m}^{2}$, a mieszańca zrestorowanego - Visby w ilości 70 nasion na $\mathrm{m}^{2}$.

Doświadczenie przeprowadzono na glebie brunatnej właściwej, kompleksu żytniego dobrego, klasy bonitacyjnej IIIa, charakteryzującej się bardzo wysoką zasobnością przyswajalnych form fosforu i potasu oraz wysoką zasobnością magnezu. Przedplonem rzepaku była pszenica jara. Siew nasion przeprowadzono w rozstawie $30 \mathrm{~cm}$, w dniach 28., 31. sierpnia w latach 2008, 2009 i 4. września $\mathrm{w}$ roku 2010. Obiekty badawcze były chronione przed chwastami i szkodnikami według zasad dobrych praktyk stosowanych w doświadczalnictwie. Chwasty dwuliścienne zwalczano herbicydem Butisan Star ${ }^{\mathrm{TM}}$ w dawce 3,0 l/ha, a samosiewy zbóż herbicydem Focus Ultra ${ }^{\mathrm{TM}} 100$ EC w dawce 1,5 l/ha. Przed szkodnikami rzepak chroniono następującymi insektycydami: $\operatorname{Karate}^{\mathrm{TM}} 025$ EC (0,25 l/ha), Proteus $^{\text {TM }} 110$ OD (0,6 l/ha), Mospilan ${ }^{\text {TM }} 20$ SP (120 g/ha). Tydzień przed zbiorem przeprowadzono desykację roślin preparatem Reglone $^{\mathrm{TM}} 200$ SL w dawce 3 1/ha. Zbiór przeprowadzono metodą jednofazową w dniach 19-21 lipca. Powierzchnia do zbioru wynosiła $9,6 \mathrm{~m}^{2}$.

Identyfikację chorób i ocenę nasilenia objawów chorobowych przeprowadzono dwukrotnie w okresie wegetacji, tj. w fazie dojrzewania (BBCH $80-20 \%$ łuszczyn dojrzałych - łodygi, BBCH 84 - 40\% łuszczyn dojrzałych łuszczyny). Określano procent pędów z objawami porażenia przez $S$. sclerotiorum oraz procent powierzchni łuszczyn z objawami powodowanymi przez Alternaria spp. i Botryotinia fuckeliana. Według dziesięciostopniowej skali bonitacyjnej, gdzie 0 - oznacza rośliny bez objawów, natomiast 9 - rośliny całkowicie porażone i pozbawione łuszczyn (Jędryczka 2006) określono stopień porażenia pędów przez Leptosphaeria spp.; stadium konidialne P. lingam. Porażenie łodyg oceniono na wszystkich roślinach na poletku, a porażenie łuszczyn na 100 łuszczynach losowo wybranych z poletka.

Dla każdego obiektu doświadczalnego określono liczbę roślin na jednostce powierzchni, liczbę łuszczyn na roślinie, liczbę nasion w łuszczynie i masę 1000 nasion. Liczbę roślin na jednostce powierzchni policzono na każdym poletku bezpośrednio przed zbiorem w trzech 
losowo wybranych miejscach na odcinku dwóch metrów bieżących. Liczbę łuszczyn na roślinie policzono na 15 kolejnych roślinach, liczbę nasion w łuszczynie na 25 losowo wybranych łuszczynach, a masę 1000 nasion w czterech próbach po 100 nasion pobranych z oczyszczonego plonu. Określono również liczbę łuszczyn zebranych z jednostki powierzchni i masę nasion $\mathrm{w}$ łuszczynie. Plon nasion w t/ha analizowano przy $12 \%$ zawartości wody. Opłacalność zastosowanych czynników wyrażono wskaźnikiem pokrycia kosztów, który obliczono w oparciu o wartość zwyżki plonu i poniesione koszty. Do obliczeń przyjęto ceny z 2011 roku.

Otrzymane wyniki podano analizie wariancji, a istotność różnic określono na poziomie ufności $\mathrm{P} \leq 0,05$. Analizę statystyczną nasilenia chorób oraz plonu i jego komponentów wykonano za pomocą pakietu statystycznego STATISTICA. W tabelach 2-4 oraz na rysunkach 1-5 przedstawiono wpływ czynników doświadczenia na analizowane cechy oraz ich istotne interakcje.

\section{Wyniki i dyskusja / Results and discussion}

Lata, w których prowadzono doświadczenie charakteryzowały zróżnicowane warunki meteorologiczne (tab. 1). Najbardziej niesprzyjający przebieg pogody dla rozwoju rzepaku odnotowano w sezonie 2010/2011. W tym okresie wystąpiło wiele niekorzystnych zjawisk atmosferycznych, które utrudniały rozwój roślin. Deszcze i niskie temperatury we wrześniu i październiku opóźniły wzrost rzepaku i rośliny przed zimą były w słabej kondycji. Niskie temperatury w okresie zimy oraz obfite deszcze na nierozmarzniętą glebę wiosną przyczyniły się do wymarznięcia i wymoknięcia wielu roślin. Rozwój rzepaku ograniczał także niedobór opadów w kwietniu i maju. Z kolei deszczowe pierwsze dwie dekady lipca utrudniały przeprowadzenie zbioru. Znacznie korzystniejsze warunki dla rozwoju rzepaku odnotowano w sezonie 2008/2009. Także w sezonie 2009/2010 warunki pogody na ogół sprzyjały tej roślinie uprawnej. W tym sezonie niekorzystne warunki pogody odnotowano jednak w czasie kwitnienia. Nadmiar opadów w tej fazie rozwojowej ograniczał wzrost i zapylenie rzepaku. Warunki pogody wpływały także na nasilenie objawów chorobowych. Porażenie roślin przez sprawców chorób determinowały również zabiegi agrotechniczne i odporność odmian. Największy wpływ na poziom nasilenia objawów chorobowych wywierały zabiegi fungicydowe oraz czynnik środowiskowy będący pochodną zmiennych w latach warunków meteorologicznych (tab. 2, 3). Zależność nasilenia chorób od warunków meteorologicznych, a zwłaszcza opadów, wilgotności i temperatury, na co zwracają uwagę Humperson-Jones i Phelps (1989), Pérés i wsp. (1999), Shrestha i wsp. (2005), Koch i wsp. (2007), Weber (2010) oraz Jajor i wsp. (2012), skutkowała dużą zmiennością intensywności porażenia rośliny uprawnej w poszczególnych sezonach wegetacyjnych. W 2009 roku odnotowano nasilenie objawów powodowanych przez S. sclerotiorum, B. fuckeliana oraz Alternaria spp. Warunki meteorologiczne w 2010 r. sprzyjały nasileniu objawów wywołanych głównie przez S. sclerotiorum, a w 2011 r. przez Alternaria spp. Nasilenie występowania wszystkich odnotowanych w doświadczeniu patogenów zostało skutecznie ograniczone w wyniku zastosowania ochrony chemicznej. Podobna efektywność sposobów ochrony była konsekwencją uwzględnienia we wszystkich programach terminów zabiegów zalecanych do zwalczania patogenów występujących w największym nasileniu w okresie prowadzenia badań czyli S. sclerotiorum i Alternaria spp. We wszystkich programach uwzględniono przeprowadzenie zabiegu w fazie opadania pierwszych płatków kwiatowych, zalecanego do zwalczania sprawców zgnilizny twardzikowej oraz czerni krzyżowych na łuszczynach. Na porażenie roślin oddziaływało również nawożenie azotem. Na obiektach nawożonych dawką azotu - $220 \mathrm{~kg}$ N/ha w porównaniu z obiektami nawożonymi dawką $160 \mathrm{~kg}$ N/ha obserwowano istotnie mniejsze nasilenie objawów chorobowych wywołane przez $S$. sclerotiorum oraz większe

Tabela 1. Warunki agroklimatyczne w trzech sezonach wegetacji rzepaku na tle wielolecia

Table 1. Agro-climatic conditions in the three growing seasons of winter oilseed rape against the background of many years' data

\begin{tabular}{c|c|c|c|c|c|c|c|c}
\hline \multirow{2}{*}{$\begin{array}{c}\text { Miesiąc } \\
\text { Month }\end{array}$} & \multicolumn{4}{|c|}{ Opady - Rainfall [mm] } & \multicolumn{4}{c}{ Temperatura - Temperature [ $\left.{ }^{\circ} \mathrm{C}\right]$} \\
\cline { 2 - 10 } & $2008 / 2009$ & $2009 / 2010$ & $2010 / 2011$ & $1957-2011$ & $2008 / 2009$ & $2009 / 2010$ & $2010 / 2011$ & $1957-2011$ \\
\hline VIII & 60,4 & 42,3 & 88,0 & 68,7 & 18,9 & 19,7 & 19,4 & 17,8 \\
\hline IX & 26,1 & 32,5 & 76,4 & 42,8 & 13,5 & 15,3 & 12,6 & 13,6 \\
\hline X & 55,4 & 63,5 & 12,6 & 38,3 & 9,5 & 7,4 & 6,3 & 8,8 \\
\hline XI & 24,8 & 35,8 & 85,8 & 41,4 & 5,5 & 6,1 & 5,6 & 3,9 \\
\hline XII & 12,3 & 48,4 & 56,6 & 39,5 & 1,7 & $-0,8$ & $-5,7$ & 0,0 \\
\hline I & 17,3 & 50,5 & 19,8 & 31,9 & $-3,1$ & $-6,5$ & 0,4 & $-1,5$ \\
\hline II & 40,1 & 15,6 & 13,5 & 32,1 & 0,1 & $-1,5$ & $-2,4$ & $-0,4$ \\
\hline III & 35,4 & 42,1 & 17,7 & 33,3 & 3,9 & 4,1 & 3,9 & 3,2 \\
\hline IV & 19,2 & 29,2 & 12,3 & 31,6 & 11,2 & 9,4 & 11,4 & 8,3 \\
\hline V & 67,5 & 148,5 & 20,9 & 54,8 & 13,8 & 12,7 & 14,5 & 13,6 \\
\hline VI & 87,8 & 40,3 & 56,7 & 66,0 & 15,7 & 17,9 & 19,3 & 16,8 \\
\hline VII & 115,2 & 63,7 & 94,2 & 82,4 & 19,5 & 22,0 & 18,3 & 18,5 \\
\hline Sezon - Season & 561,5 & 612,4 & 554,5 & 562,8 & 9,2 & 8,8 & 8,6 & 8,5 \\
\hline
\end{tabular}


Tabela 2. Wpływ intensywności ochrony za pomocą fungicydów na porażenie roślin przez sprawców chorób w latach 2009-2011

Table 2. Effect of protection intensity by fungicides on disease symptoms on plants caused by pathogens in 2009-2011

\begin{tabular}{l|c|c|c}
\hline \multirow{2}{*}{$\begin{array}{c}\text { Program ochrony (termin zabiegu) } \\
\text { Protection programme (time of application) }\end{array}$} & 2009 & 2010 & 2011 \\
\cline { 2 - 4 } & \multicolumn{3}{|c}{ \% roślin porażonych - percentage of infested plants } \\
\hline BBCH 16+33+65 & $1,1 \mathrm{~b}$ & $1,3 \mathrm{~b}$ & $0,0 \mathrm{a}$ \\
\hline BBCH 16+65 & $1,2 \mathrm{~b}$ & $1,4 \mathrm{~b}$ & $0,1 \mathrm{a}$ \\
\hline BBCH 33 + 65 & $1,9 \mathrm{~b}$ & $2,2 \mathrm{~b}$ & $0,1 \mathrm{a}$ \\
\hline Kontrola - Control & $16,4 \mathrm{a}$ & $15,9 \mathrm{a}$ & $0,3 \mathrm{a}$ \\
\hline
\end{tabular}

Leptosphaeria spp.

stopień porażenia [0-9] - degree of infestation [0-9]*

\begin{tabular}{l|l|l|c}
\hline BBCH $16+33+65$ & $0,0 \mathrm{a}$ & $0,0 \mathrm{a}$ & $0,8 \mathrm{c}$ \\
\hline BBCH $16+65$ & $0,1 \mathrm{a}$ & $0,1 \mathrm{a}$ & $1,0 \mathrm{bc}$ \\
\hline BBCH $33+65$ & $0,1 \mathrm{a}$ & $0,1 \mathrm{a}$ & $1,3 \mathrm{~b}$ \\
\hline Kontrola - Control & $0,3 \mathrm{a}$ & $0,3 \mathrm{a}$ & $2,6 \mathrm{a}$ \\
\hline
\end{tabular}

Botryotinia fuckeliana

$\%$ porażenia powierzchni łuszczyny - percentage of infected silique area

\begin{tabular}{|c|c|c|c|}
\hline $\mathrm{BBCH} 16+33+65$ & $4,9 \mathrm{~b}$ & $0,0 \mathrm{a}$ & $1,3 \mathrm{a}$ \\
\hline BBCH $16+65$ & $5,1 \mathrm{~b}$ & $0,0 \mathrm{a}$ & $1,8 \mathrm{a}$ \\
\hline ВBCH $33+65$ & $4,5 \mathrm{~b}$ & $0,0 \mathrm{a}$ & $1,5 \mathrm{a}$ \\
\hline Kontrola - Control & 6,1 a & $0,3 \mathrm{a}$ & $1,8 \mathrm{a}$ \\
\hline
\end{tabular}

*stopnie [0-9], gdzie 0 - oznacza brak objawów porażenia, a 9 - roślinę całkowicie porażoną - scale [0-9], where 0 - represents no disease symptoms, and 9 - plant completely infected

Średnie w kolumnach oznaczone tą samą literą nie różnią się istotnie według testu Tukeya $(\mathrm{p}=0,05)$ - Means in columns followed by the same letter are not significantly different according to Tukey's test $(\mathrm{p}=0.05)$

Tabela 3. Wpływ analizowanych czynników na porażenie roślin przez sprawców chorób

Table 3. Effect of experimental factors on disease symptoms on plants caused by pathogens

\begin{tabular}{|c|c|c|c|c|}
\hline \multirow[b]{2}{*}{$\begin{array}{c}\text { Czynnik/poziom } \\
\text { Factor/level }\end{array}$} & \multirow{2}{*}{$\begin{array}{c}\text { Sclerotinia sclerotiorum } \\
\text { \% roślin porażonych } \\
\text { percentage } \\
\text { of infested plants }\end{array}$} & \multirow{2}{*}{$\begin{array}{c}\text { Leptosphaeria spp. } \\
\text { stopień porażenia [0-9] } \\
\text { degree of infestation } \\
{[0-9]^{*}}\end{array}$} & Botryotinia fuckeliana & Alternaria spp. \\
\hline & & & \multicolumn{2}{|c|}{$\begin{array}{l}\text { \% porażenia powierzchni łuszczyny } \\
\text { percentage of infected silique area }\end{array}$} \\
\hline \multicolumn{5}{|c|}{ Program ochrony (termin zabiegu) - Protection programme (time of application) } \\
\hline ВBCH $16+33+65$ & $0,8 \mathrm{~b}$ & $0,3 \mathrm{bc}$ & $2,1 \mathrm{~b}$ & 3,3 bc \\
\hline $\mathrm{BBCH} 16+65$ & $0,9 \mathrm{~b}$ & $0,4 \mathrm{~b}$ & $2,3 \mathrm{~b}$ & $4,5 \mathrm{~b}$ \\
\hline $\mathrm{BBCH} 33+65$ & $1,4 \mathrm{~b}$ & $0,5 \mathrm{~b}$ & $2,0 \mathrm{~b}$ & $4,5 \mathrm{~b}$ \\
\hline Kontrola - Control & 10,9 a & $1,0 \mathrm{a}$ & 2,7 a & $7,2 \mathrm{a}$ \\
\hline \multicolumn{5}{|c|}{ Dawka azotu - Nitrogen dose [kg/ha] } \\
\hline 160 & 3,9 a & $0,5 \mathrm{a}$ & $2,1 \mathrm{~b}$ & $4,4 \mathrm{~b}$ \\
\hline 220 & $3,0 \mathrm{~b}$ & $0,6 \mathrm{a}$ & 2,5 a & 5,3 a \\
\hline \multicolumn{5}{|c|}{ Odmiana, ilość wysiewu nasion na $\mathrm{m}^{2}$ - Cultivar, sowing density per $\mathrm{m}^{2}$} \\
\hline Casoar, 80 & 3,3 a & $0,4 \mathrm{~b}$ & $2,2 \mathrm{a}$ & $5,4 \mathrm{a}$ \\
\hline Visby, 70 & 3,6 a & $0,7 \mathrm{a}$ & 2,4 a & $4,4 \mathrm{~b}$ \\
\hline \multicolumn{5}{|l|}{ Rok - Year } \\
\hline 2009 & 5,1 a & $0,1 \mathrm{~b}$ & $5,1 \mathrm{a}$ & $4,6 \mathrm{~b}$ \\
\hline 2010 & 5,2 a & $0,1 \mathrm{~b}$ & $0,1 \mathrm{~b}$ & $2,1 \mathrm{~b}$ \\
\hline 2011 & $0,1 \mathrm{~b}$ & $1,5 \mathrm{a}$ & $1,6 \mathrm{~b}$ & 7,9 a \\
\hline
\end{tabular}

*stopnie [0-9], gdzie 0 - oznacza brak objawów porażenia, a 9 - roślinę całkowicie porażoną - scale [0-9], where 0 - represents no disease symptoms, and 9 - plant completely infected

Średnie w kolumnach oznaczone tą samą literą nie różnią się istotnie według testu Tukeya $(\mathrm{p}=0,05)$ - Means in columns followed by the same letter are not significantly different according to Tukey's test $(\mathrm{p}=0.05)$ 
powodowane przez B. fuckeliana i Alternaria spp. Wyniki prezentowanego doświadczenia są zgodne ze spostrzeżeniami Jankowskiego i Budzyńskiego (1997), Söchting i Verreet (2004) oraz Wójtowicza (2013), którzy w warunkach dobrego zaopatrzenia w azot obserwowali mniejsze nasilenie objawów chorobowych sprawcy zgnilizny twardzikowej. Natomiast Lemańczyk i wsp. (1997) oraz Sadowski i wsp. (1998) nie wykazali związku pomiędzy poziomem nawożenia azotem a intensywnością występowania S. sclerotiorum. Podobną do przedstawionej w pracy reakcję $B$. fuckeliana na nawożenie azotowe opisali Jankowski i Budzyński (1997) oraz Kurowski i Budzyński (2003). Z kolei Podleśna i wsp. (2005) w podsumowaniu swojej pracy stwierdzili, że większe dawki azotu powodowały $\mathrm{z}$ reguły nasilenie objawów chorobowych rzepaku. Podobny zakres zmienności, jak poziom nawożenia azotem odnotowano pomiędzy odmianami. Odmiana Visby była istotnie mocniej porażana przez Leptosphaeria spp., a istotnie słabiej przez Alternaria spp. Jednak małe zróżnicowanie objawów chorobowych pomiędzy odmianami sugeruje, że odporność na porażenie ocenianych $\mathrm{w}$ doświadczeniu odmian nie różnicowała ich wysokości plonowania. O wysokości plonowania decydował zawarty w informacji genetycznej potencjał będący pochodną komponentów plonowania.

Komponenty plonowania były kształtowane przez wszystkie analizowane w doświadczeniu czynniki (tab. 4). Liczba roślin przed zbiorem była zróżnicowana pomiędzy latami. Najmniej roślin odnotowano w 2011 r. odznaczającym się niekorzystnymi warunkami w okresie siewów i spoczynku zimowego. Oczywistym jest fakt, że cecha ta zależała od ilości wysiewu nasion. Istotnie większą liczbą roślin na jednostce powierzchni odznaczała się wysiana w większej ilości (o 10 nasion $/ \mathrm{m}^{2}$ ) odmiana Casoar. Także liczba łuszczyn na roślinie była zróżnicowana pomiędzy latami. Najmniej łuszczyn odnotowano w 2011 r. odznaczającym się niedoborem opadów w czasie pąkowania i kwitnienia. Korzystnie na liczbę łuszczyn oddziaływały zabiegi ochronne oraz nawożenie azotem. Przeprowadzone doświadczenie potwierdziło rezultaty wcześniejszych badań Wójtowicza (2013), w których wykazano korzystny wpływ zabiegów fungicydowych na liczbę łuszczyn na roślinie. Zebrane wyniki są również zgodne z badaniami Budzyńskiego i wsp. (1995), Wójtowicza i Wielebskiego (1995), Jasińskiej i wsp. (1997), Wójtowicza i Muśnickiego (2001) oraz Wójtowicza (2013), w których udokumentowano wzrost liczby łuszczyn na roślinie pod wpływem nawożenia azotowego. Cecha ta była także zależna od odmiany i ilości wysiewu. Większą liczbą łuszczyn charakteryzowała się rzadziej wysiana odmiana Visby. Zróżnicowanie liczby łuszczyn pomiędzy odmianami wykazali Jankowski i Budzyński (2007) oraz Wójtowicz (2013). Warunki środowiskowe, zabiegi ochronne oraz poziom nawożenia azotem istotnie modyfikowały liczbę łuszczyn na jednostce powierzchni. Najmniej łuszczyn odnotowano w 2011 r. oraz na obiektach niechronionych fungicydami, a także nawożonych niższą dawką azotu. Liczba nasion w łuszczynie i masa 1000 nasion były zróżnicowane pomiędzy latami i zależały od odmiany rzepaku i ilości wysiewu. Najmniej nasion w łuszczynie obserwowano w 2011 r., a najniższą masę 1000 nasion w 2009 r. Rzadziej wysiana odmiana Visby odznaczała się większą liczbą nasion w łuszczynie,

Tabela 4. Wpływ czynników doświadczenia na komponenty plonu

Table 4. Effect of experimental factors on yield components

\begin{tabular}{|c|c|c|c|c|c|c|}
\hline $\begin{array}{l}\text { Czynnik/poziom } \\
\text { Factor/level }\end{array}$ & $\begin{array}{c}\text { Liczba roślin } \\
\text { na } 1 \mathrm{~m}^{2} \\
\text { Number } \\
\text { of plants } \\
\text { per } 1 \mathrm{~m}^{2}\end{array}$ & $\begin{array}{l}\text { Liczba łuszczyn } \\
\text { na roślinie } \\
\text { Number } \\
\text { of siliques } \\
\text { per plant }\end{array}$ & $\begin{array}{l}\text { Liczba } \\
\text { łuszczyn } \\
\text { na } 1 \mathrm{~m}^{2} \\
\text { Number } \\
\text { of siliques } \\
\text { per } 1 \mathrm{~m}^{2}\end{array}$ & $\begin{array}{c}\text { Liczba nasion } \\
\text { w łuszczynie } \\
\text { Number } \\
\text { of seeds } \\
\text { per silque }\end{array}$ & $\begin{array}{c}\text { Masa } \\
1000 \text { nasion } \\
\text { Weight } \\
\text { of } 1000 \text { seeds } \\
\text { [g] }\end{array}$ & $\begin{array}{c}\text { Masa nasion } \\
\text { w łuszczynie } \\
\text { Weight } \\
\text { of seeds } \\
\text { per silque } \\
\text { [mg] }\end{array}$ \\
\hline \multicolumn{7}{|c|}{ Program ochrony (termin zabiegu) - Protection programme (time of application) } \\
\hline BBCH $16+33+65$ & $43,9 \mathrm{a}$ & $214 \mathrm{a}$ & 9395 a & $21,3 \mathrm{a}$ & $5,31 \mathrm{a}$ & 111,7 a \\
\hline BBCH $16+65$ & $42,7 \mathrm{a}$ & 215 a & 9181 a & 21,3 a & 5,38 a & $113,6 \mathrm{a}$ \\
\hline ВBCH $33+65$ & $42,4 \mathrm{a}$ & $211 \mathrm{a}$ & 8946 a & $20,8 \mathrm{a}$ & $5,28 \mathrm{a}$ & 108,8 a \\
\hline Kontrola - Control & $36,7 \mathrm{a}$ & $181 \mathrm{~b}$ & $6643 \mathrm{~b}$ & $21,2 \mathrm{a}$ & $5,31 \mathrm{a}$ & $111,6 \mathrm{a}$ \\
\hline \multicolumn{7}{|c|}{ Dawka azotu - Nitrogen dose [kg/ha] } \\
\hline 160 & $40,4 \mathrm{a}$ & $194 \mathrm{~b}$ & $7838 \mathrm{~b}$ & 21,3 & $5,32 \mathrm{a}$ & $112,2 \mathrm{a}$ \\
\hline 220 & $42,4 \mathrm{a}$ & 217 a & $9201 \mathrm{a}$ & 21,0 & $5,32 \mathrm{a}$ & $110,6 \mathrm{a}$ \\
\hline \multicolumn{7}{|c|}{ Odmiana, ilość wysiewu nasion na $\mathrm{m}^{2}-$ Cultivar, sowing density per $\mathrm{m}^{2}$} \\
\hline Casoar, 80 & $44,7 \mathrm{a}$ & $187 \mathrm{~b}$ & 8359 a & $18,9 \mathrm{~b}$ & $5,57 \mathrm{a}$ & $105,2 \mathrm{~b}$ \\
\hline Visby, 70 & $38,1 \mathrm{~b}$ & 224 a & 8534 a & 23,3 a & $5,07 \mathrm{~b}$ & 117,7 a \\
\hline \multicolumn{7}{|c|}{ Rok - Year } \\
\hline 2009 & 58,4 a & $213 a b$ & 12439 a & $23,2 \mathrm{a}$ & $4,76 \mathrm{~b}$ & 109,8 a \\
\hline 2010 & 44,2 a & 222 a & 9812 a & $20,5 \mathrm{ab}$ & 5,62 a & 115,2 a \\
\hline 2011 & $21,6 \mathrm{~b}$ & $181 \mathrm{~b}$ & $3910 \mathrm{~b}$ & $19,7 \mathrm{~b}$ & 5,59 a & 109,3 a \\
\hline
\end{tabular}

Średnie w kolumnach oznaczone tą samą literą nie różnią się istotnie według testu Tukeya $(\mathrm{p}=0,05)$ - Means in columns followed by the same letter are not significantly different according to Tukey’s test $(\mathrm{p}=0.05)$ 
Tabela 5. Opłacalność zastosowanych czynników

Table 5. Profitability of applied factors

\begin{tabular}{l|c}
\hline \multicolumn{1}{c|}{$\begin{array}{c}\text { Porównanie zastosowanych czynników } \\
\text { Comparison of applied factors }\end{array}$} & $\begin{array}{c}\text { Wskaźnik pokrycia } \\
\text { kosztów } \\
\text { Cost defrayl index }\end{array}$ \\
\hline $\begin{array}{l}\text { Ochrona w fazie BBCH } 16+33+65 \text { vs brak ochrony } \\
\text { Protection in phase BBCH } 16+33+65 \text { vs lack of protection }\end{array}$ & 1,4 \\
\hline Ochrona w fazie BBCH 16 + 65 vs brak ochrony - Protection in phase BBCH 16 + 65 vs lack of protection & 1,4 \\
\hline Ochrona w fazie BBCH 33 + 65 vs brak ochrony - Protection in phase BBCH 33 + 65 vs lack of protection & 1,5 \\
\hline Zwiększenie intensywności nawożenia z 160 do 220 kg N/ha & 3,4 \\
\hline Increase of nitrogen fertilization intensity from 160 to $220 \mathrm{~kg}$ N/ha & \\
\hline
\end{tabular}

a odmiana Casoar większą masą 1000 nasion. Odmianę Visby charakteryzowała także większa masa nasion w łuszczynie. Znaczące różnice wartości tych cech pomiędzy odmianami wykazali w swych pracach Jankowski i Budzyński (2007) oraz Wielebski (2007). Natomiast Muśnicki i Muśnicka (1986) oraz Wójtowicz (2013) zwracają uwagę, że mała zmienność masy nasion w łuszczynie przy wysokich wartościach tej cechy przyczynia się do ograniczenia strat plonu w warunkach niesprzyjających rozwojowi tej rośliny uprawnej.

Istotność powyższej informacji doceniają hodowcy, ponieważ występowanie niekorzystnych warunków dla rozwoju i plonowania rzepaku nie należy w Polsce do

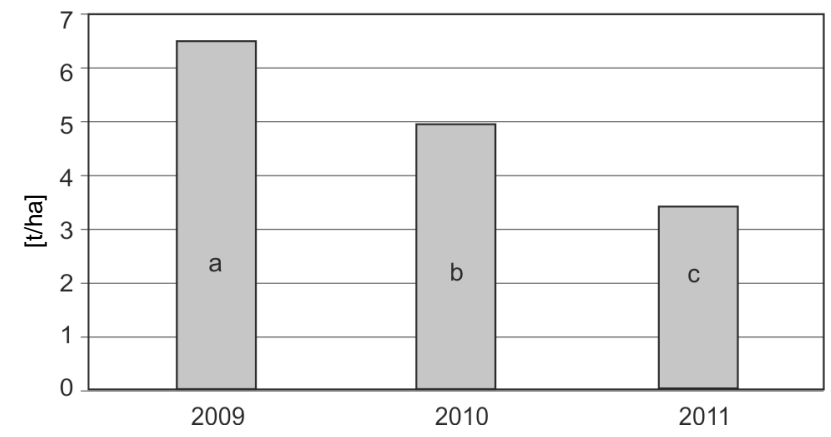

Rys. 1. Wpływ warunków środowiskowych na poziom plonowania Fig. 1. Effect of environmental conditons on yield level

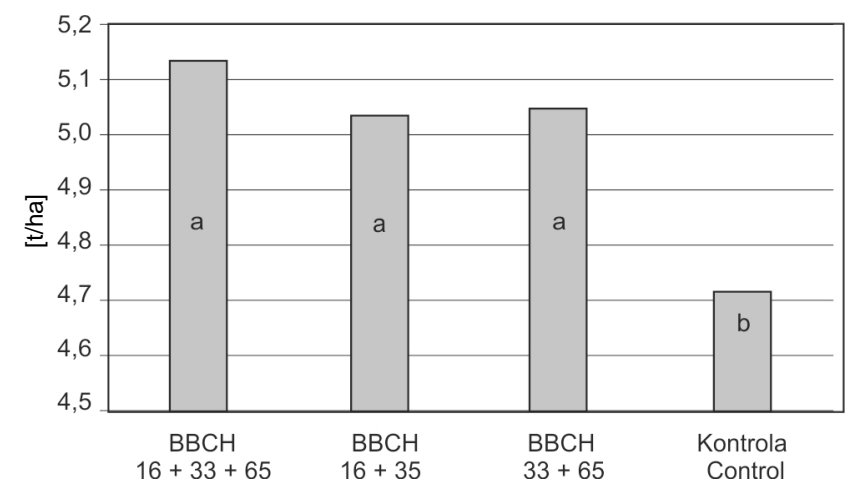

Rys. 3. Wpływ intensywności ochrony za pomocą fungicydów na poziom plonowania

Fig. 3. Effect of protection intensity by fungicides on yield level rzadkości. Również w trakcie omawianych 3-letnich badań jeden sezon - 2010/2011 był wyjątkowo niekorzystny dla rozwoju rzepaku, co skutkowało niskimi plonami. Uzyskany w 2011 r. plon nasion rzepaku był niższy o ponad 3 i 1,5 t/ha od odnotowanego odpowiednio w latach 2009 i 2010 (rys. 1). Porównanie zróżnicowania wysokości plonowania będącego następstwem zmienności warunków meteorologicznych $\mathrm{w}$ latach prowadzenia doświadczenia ze zmiennością tej cechy spowodowanej przez pozostałe czynniki doświadczenia wskazuje na rolę zaspokojenia potrzeb wodnych i termicznych rzepaku w kształtowaniu tej najważniejszej cechy rolniczej. Spośród ocenianych

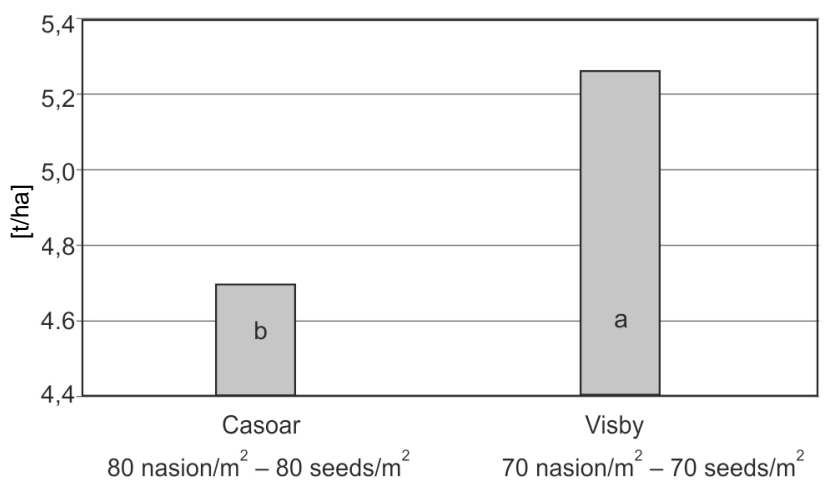

Rys. 2. Wpływ odmiany i ilości wysiewu na poziom plonowania Fig. 2. Effect of cultivar and sowing density on yield level

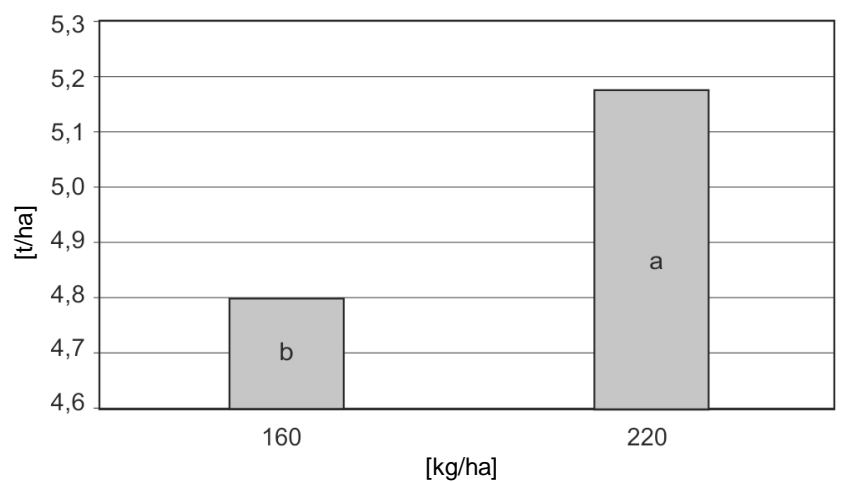

Rys. 4. Wpływ nawożenia azotem na poziom plonowania Fig. 4. Effect of nitrogen fertilization on yield level 


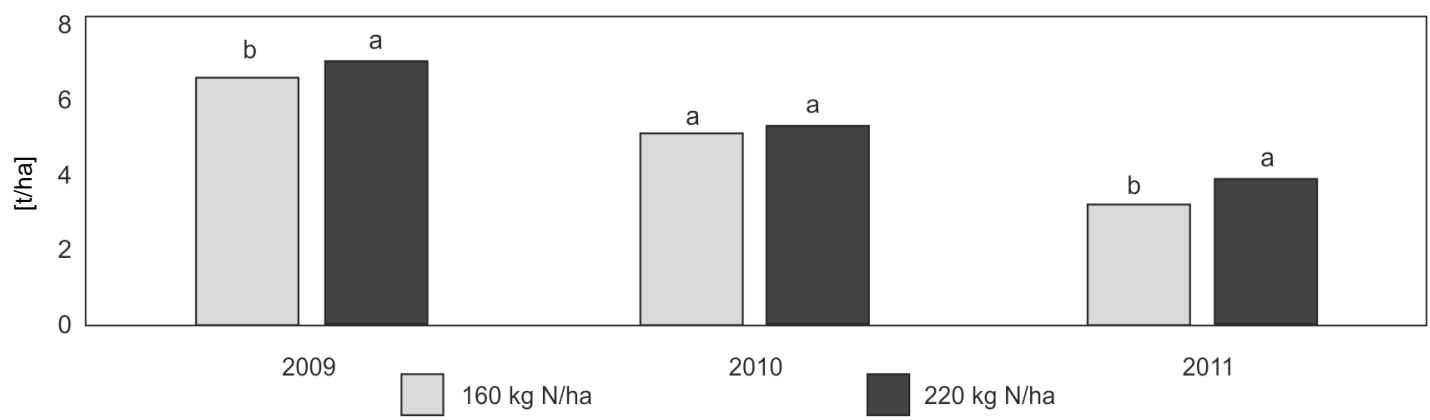

Rys. 5. Wpływ nawożenia azotem na poziom plonowania w zmiennych warunkach środowiskowych

Fig. 5. Effect of nitrogen fertilization on yield level under different environmental conditions

w doświadczeniu czynników, poziom plonowania w największym stopniu determinowała odmiana i ilość wysiewu. Rzadziej wysiana odmiana Visby plonowała średnio ponad 0,5 t/ha wyżej od odmiany Casoar (rys. 2). Rolę odmiany na tle innych czynników uwypuklają również badania Budzyńskiego i wsp. (1985), Wójtowicza i wsp. (2002) oraz Wójtowicza i Czernik-Kołodziej (2003). Także Jankowski (2001) wykazując niskie koszty materiału siewnego i wysiewu nasion, które stanowia zaledwie $3 \%$ kosztów uprawy rzepaku zwraca uwagę na korzyści płynące $\mathrm{z}$ wyboru odmiany do uprawy. W realizowanym doświadczeniu program ochrony różnicował wysokość plonu w zakresie około 0,4-0,3 t/ha (rys. 3). Natomiast rezultatem zwiększenia nawożenia z 160 do $220 \mathrm{~kg} \mathrm{~N} / \mathrm{ha}$ był średni wzrost plonu o około 0,4 t/ha (rys. 4). Przeprowadzone doświadczenie potwierdziło zależność efektywności nawożenia azotowego od warunków wilgotnościowych. W 2010 r. charakteryzującym się nadmiarem opadów w maju nie odnotowano wzrostu plonowania w wyniku zwiększonego nawożenia azotem (rys. 5). Prezentowane wyniki uzupełniają zatem wcześniejsze doniesienia Barszczaka i wsp. (1994), Wielebskiego i Wójtowicza (1994) oraz Barszczaka i Barszczak (1995), którzy obserwowali wpływ niedoboru opadów na ograniczenie efektywności nawożenia azotowego. Podsumowując prezentowane wyniki badań należy podkreślić rolę intensywności uprawy dla wysokości plonu i opłacalności uprawy. Opłacalne okazały się wszystkie sposoby ochrony (tab. 5). Wskaźnik pokrycia kosztów dla ochrony prowadzonej w fazach: BBCH $16+33+65$; $\mathrm{BBCH} 16+65$;
BBCH $33+65$ wynosił odpowiednio 1,$4 ; 1,4 ; 1,5$. Opłacalne było również zwiększenie intensywności nawożenia z 160 do $220 \mathrm{~kg} \mathrm{~N} /$ ha (tab. 5). Wskaźnik pokrycia kosztów dla tego czynnika wynosił 3,4. Powyższe dane wpisują się w wyniki badań Budzyńskiego i wsp. (2005), które wykazują znaczenie intensyfikacji technologii dla opłacalności produkcji rzepaku. Należy podkreślić zatem znaczenie czynnika plonotwórczego nawożenia azotowego i plonochronnego - ochrony przed sprawcami chorób dla wysokości plonowania zarówno odmiany populacyjnej, jak i mieszańcowej.

\section{Wnioski / Conclusions}

1. Zależność nasilenia objawów chorobowych od zmiennych w latach warunków meteorologicznych oraz podobna efektywność zastosowanych programów ochrony wskazuje na potrzebę rozwijania systemów wspomagających podejmowanie decyzji w ochronie rzepaku przed najgroźniejszymi patogenami tej rośliny uprawnej.

2. Małe zróżnicowanie nasilenia objawów chorobowych w efekcie zastosowanego nawożenia azotowego sprzyja intensyfikacji technologii produkcji rzepaku.

3. Intensyfikacja nawożenia azotowego przyczyniając się do wytworzenia przez roślinę większej liczby łuszczyn skutkuje zwiększeniem plonu i opłacalności zastosowanego zabiegu.

\section{Literatura / References}

Barszczak T., Barszczak Z. 1995. Wpływ nawożenia azotowego, wilgotności i zakwaszenia gleby na plony oraz zawartość thuszczu i białka w nasionach odmian rzepaku ozimego. [Effect of nitrogen fertilization, soil moisture and acidity on seed yield and protein content in seeds of winter oilseed rape cultivars]. Rośliny Oleiste - Oilseed Crops 16 (1): 165-172.

Barszczak Z., Barszczak T., Kosjanowicz W. 1994. Wpływ okresowej suszy i dawek azotu na plony i skład chemiczny nasion odmian rzepaku ozimego. [Effect of periodical drought and nitrogen rates on seed yields and chemical composition of winter oilseed rape cultivars]. Rośliny Oleiste - Oilseed Crops 15 (2): 9-16.

Budzyński W.S., Jankowski K.J., Rybacki R. 2005. Poziom ochrony a plon nasion rzepaku ozimego w gospodarstwach wielkoobszarowych. [Relation between plant protection measures and yield of oilseed rape in big area farms]. Rośliny Oleiste Oilseed Crops 26 (2): 421-436.

Budzyński W., Majkowski K., Horodyski A., Jasińska Z., Jodłowski M., Muśnicki Cz., Orłowska T., Owczarek W. 1985. Wpływ poziomu i terminu wiosennego nawożenia azotem na plonowanie odmian rzepaku ozimego. [Effect of the level and date of the nitrogen fertilization in spring on yielding of winter rape varieties]. Biuletyn Instytutu Hodowli i Aklimatyzacji Roślin - Bulletin of Plant Breeding and Acclimatization Institute 157: 123-134. 
Budzyński W., Ojczyk T., Toboła P., Malarz W. 1995. Porównanie doglebowego i dolistnego nawożenia rzepaku ozimego mocznikiem. [Comparison of soi land foliar urea application to winter oilseed rape]. Rośliny Oleiste - Oilseed Crops 16 (1): 151-156.

Humperson-Jones F.M., Phelps K. 1989. Climatic factors influencing spore production of Alternaria brassicae and Alternaria brassicicola. Annals of Applied Biology 114 (3): 449-458.

Jajor E., Horoszkiewicz-Janka J., Danielewicz J., Korbas M. 2012. Wpływ zmianowania i fungicydów na ograniczanie występowania chorób rzepaku ozimego. [Influence of crop rotation and fungicides on occurrence limitation of winter oilseed rape diseases]. Progress in Plant Protection/Postępy w Ochronie Roślin 52 (4): 1011-1015.

Jankowski K. 2001. Economic efficiency of different technologies of production of raw materials for oil production. Międzynarodowa Konferencja Naukowa „Intenivani olejniny”. Praga, 11-12.12.2001: 38-43.

Jankowski K., Budzyński W. 1997. Nawożenie azotem a stopień uszkodzeń rzepaku ozimego przez szkodniki. [Nitrogen fertilization and the degree of damages of winter rape caused by insect pests]. Zeszyty Problemowe Postępów Nauk Rolniczych 439: $273-280$.

Jankowski K., Budzyński W. 2007. Reakcja różnych form hodowlanych rzepaku ozimego na termin i gęstość siewu. II. Plon nasion $\mathrm{i}$ jego składowe. [Response of different breeding forms of winter oilseed rape to date and density of sowing II. Seed yield and yield components]. Rośliny Oleiste - Oilseed Crops 28 (2): 195-207.

Jasińska Z., Kotecki A., Kozak M. 1997. Wpływ następczy roślin strączkowych i nawożenia azotem na rozwój i plon rzepaku ozimego. [Residual effects of leguminous crops and nitrogen fertilization on the development and yield of winter oilseed rape (Brassica napus)]. Rośliny Oleiste - Oilseed Crops 18 (1): 187-198.

Jędryczka M. 2006. Epidemiologia i szkodliwość suchej zgnilizny kapustnych na rzepaku ozimym w Polsce. Rozprawy i Monografie Instytut Genetyki Roślin Polskiej Akademii Nauk 17, 150 ss.

Koch S., Dunker S., Kleinhenz B., Röhring M., Tiedmann A. 2007. A crop loss-related forecasting model for Sclerotinia stem rot in winter oilseed rape. Phytopathology 97: 1186-1194.

Kurowski T.P., Budzyński W. 2003. Wpływ zróżnicowanego nawożenia azotem i ochrony przed szkodnikami na zdrowotność rzepaku jarego. [The influence of differentiated nitrogen fertilization and insect control on sanitary state of spring oilseed rape]. Rośliny Oleiste - Oilseed Crops 24 (2): 455-463.

Lemańczyk G., Jankowski K., Sadowski C., Klepin J., Muchalski T. 1997. Wpływ zróżnicowanego nawożenia azotowego i zaniechania zwalczania szkodników na zdrowotność rzepaku ozimego. [Effect of differentiated nitrogen fertilization and desistance from pest control on the heath status of rapeseed]. Rośliny Oleiste - Oilseed Crops 18 (2): 371-379.

Marschner H. 1995. Relationships between mineral nutrition and plant diseases and pests. p. 436-460. In: ”Mineral Nutrition of Higher Plants”. Academic Press, 862 pp.

Mączyńska A., Głazek M., Krzyzińska K., Banachowska J. 2001. Porażenie przez grzyby chorobotwórcze roślin rzepaku ozimego w latach 1999 i 2000. [Occurrence of winter oilseed rape pathogens in 1999 and 2000 years]. Rośliny Oleiste - Oilseed Crops 22 (1): 127-138.

Muśnicki Cz., Muśnicka B. 1986. Struktura plonowania różnych typów jakościowych rzepaku ozimego. [The structure of yield of different quality types of winter rape]. Zeszyty Problemowe Instytutu Hodowli i Aklimatyzacji Roślin 9: 107-122.

Pérés A., Poission B., Le Sourne V., Maisonneuve C. 1999. Leptosphaeria maculans: Effects of temperature, rainfall and humidity on the formation of pseudothecia. Proceedings of the 10th International Rapeseed Congress. Canberra, Australia, September 26-29, 1999. http://www.regional.org.au/au/gcirc/index.htm

Podleśna A., Jędryczka M., Lewartowska E. 2005. Występowanie chorób grzybowych na rzepaku ozimym w warunkach zróżnicowanego nawożenia siarką i azotem. [The occurrence of fungal diseases on winter oilseed rape in the conditions of differentiated sulphur and nitrogen fertilization]. Rośliny Oleiste - Oilseed Crops 26 (1): 173-184.

Sadowski Cz., Baturo A., Lenc L., Trzciński J. 2002. Występowanie mączniaka rzekomego (Peronospora parasitica /Pers. Ex Fr./Fr.) i mączniaka prawdziwego (Erysiphe cruciferarum Opiz ex L. Junell) na rzepaku jarym odmiany Star przy zróżnicowanym nawożeniu azotem i siarką. [Downy mildew (P. parasitica) and powdery mildew (E. cruciferarum) occurrence on spring oilseed rape cv. Star depending on differentiated fertilization with nitrogen and sulphur]. Rośliny Oleiste - Oilseed Crops 23 (2): $391-408$.

Sadowski Cz., Musnicki C., Lemanczyk G., Drozdowska L., Trzcińska E. 1998. Effect of different nitrogen fertilization and absence of pest control on health status of rapeseed. Integrated control in oilseed crops. Bulletin OILB/SROP 21 (5): 221-226.

Shrestha K.S., Munk L., Mathur B. 2005. Role of weather on Alternaria leaf blight disease and its effect on yield and yield components of mustard. Nepal Agriculture Research Journal 6: 62-72.

Söchting H.P., Verreet J.-A. 2004. Effects of different cultivation systems (soil management, nitrogen fertilization) on the epidemics of fungal diseases in oilseed rape (Brassica napus L. var. napus). Zeitschrift für Pflanzenkrankheiten und Pflanzenschutz Journal of Plant Diseases and Protection 111 (1): 1-29.

Starzycka E., Starzycki M., Kauzik M., Woś H., Cichy H., Budzianowski G. 2009. Ocena odporności rzepaku ozimego na porażenie przez Leptosphaeria spp. i Sclerotinia sclerotiorum (Lib.) de Bary w doświadczeniach przeprowadzonych w Małyszynie i Borowie, w latach 2007-2009. [Evaluation of winter rape resistance to Leptosphaeria spp. and Sclerotinia sclerotiorum (Lib.) de Bary in trials conducted in Małyszyn and Borowo in 2007-2009]. Rośliny Oleiste - Oilseed Crops 30 (2): 207-222.

Weber Z. 2010. Fitopatologia. Tom 1. PWRiL, Poznań, 639 ss.

Wielebski F. 2007. Reakcja różnych typów odmian rzepaku ozimego na zmienne zagęszczenie roślin w łanie I. Plon nasion i jego składowe. [Response of different types of winter oilseed rape varieties to various plant density in the field I. Seed yield and its components]. Rośliny Oleiste - Oilseed Crops 28 (2): 209-226.

Wielebski F., Wójtowicz M. 1994. Wpływ okresowych niedoborów wody przy zróżnicowanym nawożeniu azotowym na plon i zawartość glukozynolanów w nasionach rzepaku ozimego. [Influence of water deficit and differentiated nitrogen fertilization on winter double low oilseed rape seed yield and glucosinolate content]. Rośliny Oleiste - Oilseed Crops 15 (2): 27-34.

Wójtowicz M. 2013. Rola czynników środowiskowych i agrotechnicznych w kształtowaniu wielkości i jakości plonu rzepaku ozimego (Brassica napus L.). [Effect of environmental and agronomical factors on quantity and quality of winter oilseed rape yield (Brassica napus L.)]. Monografie i rozprawy naukowe 45/2013. Instytut Hodowli i Aklimatyzacji Roślin - Państwowy Instytut Badawczy, Radzików.

Wójtowicz M., Czernik-Kołodziej K. 2003. Reakcja zarejestrowanych odmian rzepaku ozimego na poziom agrotechniki. [Response of registered winter oilseed rape cultivars to the level of agronomical practices]. Rośliny Oleiste - Oilseed Crops 24 (1): 85-94. 
Wójtowicz M., Muśnicki Cz. 2001. Udział komponentów struktury w kształtowaniu plonu nasion podwójnie ulepszonych odmian rzepaku ozimego. [Contribution of yield components in creation of the seed yield of double low winter oilseed rape]. Roczniki Akademii Rolniczej w Poznaniu, CCCXXXV, Rolnictwo 61: 105-121.

Wójtowicz M., Wielebski F. 1995. Wpływ wiosennego nawożenia azotem przy różnym uwilgotnieniu gleby na plon, elementy plonotwórcze i zawartość glukozynolanów w nasionach trzech odmian rzepaku ozimego. [Influence of spring nitrogen fertilization by various soil moisture on yield, yield components and seed quality of three cultivars of winter oilseed rape]. Rośliny Oleiste Oilseed Crops 16 (1): 157-164.

Wójtowicz M., Wielebski F., Czernik-Kołodziej K. 2002. Wpływ wiosennego nawożenia azotem na cechy rolnicze i użytkowe nowych form hodowlanych rzepaku ozimego. [Effect of spring nitrogen fertilization on agronomical and commercial plant characters of new breeding forms of winter oilseed rape]. Rośliny Oleiste - Oilseed Crops 23 (2): 337-350. 